\section{Vietnam Journal of Agricultural Sciences}

\title{
Characterization of Variovorax Strain C6d Isolated from the Algae-bacteria Consortia
}

\author{
Vu Thi Hoan \\ Faculty of Natural Resources and Environment, Vietnam National University of \\ Agriculture, Hanoi 131000, Vietnam
}

\begin{abstract}
The rhizosphere microorganisms can form beneficial, pathogenic, or neutral relationships. These relationships can promote plant growth and productivity. Among them, a number of Variovorax isolates from the rhizosphere were isolated. Bacteria Variovorax strain C6d (AB552893) was isolated from the non axenic culture of Chlorella spp., C6. The cell was Gram-negative, motile, non-spore-forming, short and rod-shaped $(0.5-1.0 \times 1.5-2.0 \mu \mathrm{m})$. Colonies were in white colour after 7 days on 10-fold diluted Nutrient Broth. The strain was able to tolerate $\mathrm{NaCL}$ to $1.0 \%$ but not to $4.0 \%$ of $\mathrm{NaCl}$. It grew quite well at temperatures ranging from $10^{\circ} \mathrm{C}$ to $37^{\circ} \mathrm{C}$, yet did not show any growth at $4^{\circ} \mathrm{C}$ and $42^{\circ} \mathrm{C}$. The dominant isoprenoid quinone was ubiquinone $8(\mathrm{Q} 8)$. The major fatty acid composition of this strain was summed feature 3,16:0 and 18:1:w7. The DNA G+C content of strain C6d was $70.4 \mathrm{~mol} \%$.
\end{abstract}

\section{Keywords}

Variovorax, Characterization, algae-bacteria consortia

\section{Introduction}

The phycosphere is the zone surrounding an algal cell within which microorganisms are influenced by algal products. Not a small number of microalgae are living in soil, and the phycosphere in soil may represent a good microhabitat for soil bacteria. Studies on the associations between green microalgae (phylum Chlorophyta, kingdom Plantae) and bacteria are considered to be of great value, because the form is not only a microorganism-microorganism association but, at the same time, may also be a primitive plantmicroorganism association.

Rhizosphere microbes that can form beneficial, pathogenic, or neutral relationships. Understanding these associations can inform strategies for manipulating the plant's microbiome to promote plant growth and productivity. Among the microorganisms isolated from the rhizosphere are a number of Variovorax isolates (Jennifer, 2019). Variovorax are known for degrading a variety of toxins and organic compounds (Futamata et al., 2005). Variovorax also plays an

Correspondence to vthoan@vnua.edu.vn Received: September 24, 2020
Accepted: August 18, 2021 
important role in the natural cycling of biogenic chemicals including degrading a variety of contaminants such as pesticides (Han et al., 2011).

The genus Variovorax belongs to the family Comamonadaceae in the class Betaproteobacteria, phylum Proteobacteria. The species Variovorax paradoxus was originally described as Alcaligenes paradoxus by Davis in 1969 and re-classified by Willems et al. in 1991 as $V$. paradoxus. Four other members have so far been described, Variovorax dokdonensis Yoon et al. (2006a), Variovorax soli (Kim et al., 2006), Variovorax boronicumulans (Miwa et al., 2008), and Variovorax ginsengisoli (Im et al. 2010; Tuan et al., 2018) reported three more novel species of soil bacteria, Variovorax ureilyticus, Variovorax rhizosphaerae, and Variovorax robiniae.

Variovorax are microorganisms of interested due to their diverse metabolic capabilities. Many species of Variovorax have been isolated from contaminated soils and groundwater around the world and of those, some are able to biodegrade of both biogenic compounds and anthropogenic contaminants. For example, Mahan et al. (2017) isolated Variovorax sp. strain JS1663 that was able to degraded N-nitroglycine (NNG). This is the key enzyme involved in its catabolism. The interaction between Variovorax with other microbe and/or plants makes $V$. paradoxus ideal for studies investigating its potential for different applications.

Variovorax strain $C 6 d$ was isolated from the culture of Chlorella spp., and C6 was initially isolated in November 2005 from the soil collected in the experimental field of the University of Tokyo, Japan (Otsuka et al., 2008a). The algal culture has been maintained without purification in $\mathrm{C}$ liquid medium (Ichimura, 1971) for long term. The cultivation conditions were a 16:8 light-dark cycle with a light intensity of about $10-20 \mu \mathrm{mol}$ photons $\mathrm{m}^{-2}$ $\mathrm{s}^{-1}$ at $25^{\circ} \mathrm{C}$ in the light and $20^{\circ} \mathrm{C}$ in the dark. The algal culture was serial subcultivated once every four weeks. C medium contains no carbon sources for general heterotrophic bacteria ( $\mathrm{Vu}$ et al., 2010).
Currently, few studies the characterization of Variovorax isolated from algal cultures have been reported. In this study, the taxonomic position of the bacteria Variovorax strain C6d is discussed based on phenotypic, genotypic and chemotaxonomic properties. This study gave us a good understanding of the bacteria associated with Chlorella, and opened a chance for conducting further studies on the effects of the consortia on the soil and environment.

\section{Materials and Methods}

\section{Identification of bacteria}

DNA of the isolate was extracted according to Ashida et al. (2010). The almost full length of the $16 \mathrm{~S}$ ribosomal RNA (rRNA) gene of the isolate was amplified by polymerase chain reaction (PCR) with the forward primer $27 \mathrm{~F}$ and the reverse primer 1492R that corresponds to the positions

8-27

(AGAGTTTGATCCTGGCTCAG) and 15101492 (GGTTACCTTGTTACGACTT) in the Escherichia coli 16S rRNA gene numbering, respectively and a thermal cycler GeneAmp PCR system 9700 (Applied Biosystems, Foster City, CA, USA). The amplification was carried out with the initial denaturation step at $94^{\circ} \mathrm{C}$ for $10 \mathrm{~min}$, then 27 cycles including denaturation at $94^{\circ} \mathrm{C}$ for $30 \mathrm{sec}$, annealing at $55^{\circ} \mathrm{C}$ for $30 \mathrm{sec}$, and extension at $72^{\circ} \mathrm{C}$ for $1 \mathrm{~min}$. The final extension was done at $72^{\circ} \mathrm{C}$ for $7 \mathrm{~min}$, and then the mixtures were held at $4^{\circ} \mathrm{C}$. Amplification of the PCR products of the proper size was confirmed by electrophoresis through a $1.5 \%$ agarose gel, followed by staining with ethidium bromide. MicroSpin S-400 HR columns (GE Healthcare Biosciences, Oslo, Norway) were used to purify the amplified products then directly sequenced as described by Saito et al. (2008). The DNA sequence chromatograms were edited and analyzed by using Finch TV ver. 1.4 (Geospiza, Seattle, WA, USA; http://www.geospiza.com/finchtv/) software and bidirectional sequences were aligned by Clustal W ver. 2.0 (Larkin et al., 2007) to obtain the consensus sequence for each region of the $16 \mathrm{~S}$ rRNA gene of a strain. The type strains of species phylogenetically closely related to the 
isolated strains were searched for using the SeqMatch program (Cole et al., 2007) based on the similarity of the almost full-length $16 \mathrm{~S}$ rRNA gene sequences. Clustal $\mathrm{W}$ version 2.0 program was used to analyse the phylogenetic relationships of the isolated strains and the closely related species, and identify the strains at the genus level.

\section{Gram staining and morphological characteristics}

Gram staining was conducted based on the described methods by Gerhardt et al. (1994). The morphological characteristics of the cells were observed by photos taken by JEOL Datum (Tokyo, Japan) using transmission electron microscopy with negative staining.

\section{Physiological tests}

The physiological profile of the strains was determined using API 20NE microtest galleries (bioMérieux ${ }^{\circledR}$ S.A., Marcy-l'Etoile, France) according to the manufacture's instructions. In addition, Biolog Gen III MicroPlate (Biolog, Inc) that allows testing 71carbon source and 23 chemical sensitivity was used to determine the assimilation and the oxidation patterns of these strains, respectively.

The growth of the bacteria at $4,10,15,20$, $26,30,37$, and $42^{\circ} \mathrm{C}$ was determined by adding $100 \mu \mathrm{L}$ of the subculture into a glass tube containing pure $10 \mathrm{~mL}$ of pure $10^{-1} \mathrm{NB}$ medium and evaluated after two weeks of the inoculation started. The growth of the bacteria was determined by the measurement of the OD at 600 $\mathrm{nm}$ compared to a blanked control of the culture media without bacteria.

\section{Isoprenoid quinones}

The isoprenoid quinones were extracted and analyzed according to the method described by Collins \& Jones (1981) with some modifications. The bacterial cells were vacuum freeze-dried in Freevac (Tozai Tsusho Co., Ltd, Japan) to remove the water content. About 100mg of dried cells was transferred to a $100-\mathrm{mL}$ glass flask and covered with by aluminium foil. Twenty milliliters $(20 \mathrm{~mL})$ of extraction solvent (chloroform - methanol 2:1) was added and stirred for $2 \mathrm{~h}$ at room temperature. The sample solution was filtered by a $5 \mathrm{~A}$ Advantec filter paper (Advantec, Toyo Roshi Kaisha, Ltd., Japan). The procedure was repeated. The filtrates were combined and evaporated in vacuo using a rotary evaporator (R-3000 Rotavapor; Büchi Labortechnik AG, Germany) at 40rpm at $30^{\circ} \mathrm{C}$. The quinones were extracted again by using $5 \mathrm{~mL}$ of acetone and evaporated in the vacuo. Twohundred microliters $(200 \mu \mathrm{L})$ of $99.5 \%$ methyl ethanol was added to dissolve the quinones. The quinone fractions and the reference quinones were separated by thin-layer chromatography (TLC) using silica gel 60F (Merck, Ltd., Japan) and developed in the chromatographic chamber containing $100 \mathrm{~mL}$ hexane-diethyl ether $(85: 15)$. After drying the quinone spots were detected under UV light at $275 \mathrm{~nm}$. The quinone spots were scraped off and collected in a tube and $500 \mu \mathrm{L}$ of acetone was added to extract the quinones. The quinone solution was concentrated by a stream of $\mathrm{N}_{2}$ gas and dissolved in $200 \mu \mathrm{L}$ of ethanol. The extracted quinones and the reference quinones were analyzed by a highperformance liquid chromatography (HPLC) (Shimadzu, Kyoto, Japan) equipped with a 5C18R Cosmosil column (Nacalai Tesc) and using methanol-isopropanol $(2: 1)$ as the solvent. The oven temperature was set at room temperature with a pump rate of $1 \mathrm{~mL} \mathrm{~min}^{-1}$, and chromatograms were read at $270 \mathrm{~nm}$.

\section{Whole cellular fatty acids}

Whole cellular fatty acids of the bacteria were extracted and analyzed according to the Sherlock Microbial Identification (MIDI) systems. The cell sample was saponified with $1 \mathrm{~mL}$ of Sherlock Reagent 1, shook for $10 \mathrm{sec}$ and heated at $100^{\circ} \mathrm{C}$ for $5 \mathrm{~min}$, then shook again for $10 \mathrm{sec}$ and re-heated for $25 \mathrm{~min}$. After a total of 30 min of saponification in the water bath at $100^{\circ} \mathrm{C}$, the sample was cooled in a cold tap water to room temperature. The cell suspension was methylated with $2 \mathrm{~mL}$ of Sherlock Reagent 2, shook for five to ten seconds, heated at $80^{\circ} \mathrm{C} \pm 1{ }^{\circ} \mathrm{C}$ for $10 \mathrm{~min}$, and cooled rapidly to room temperature. The fatty acid methyl esters were extracted by adding $1.25 \mathrm{~mL}$ of Sherlock Reagent 3 and gently mixed 
for 10min. The lower phase was removed and discarded by Pasteur pipette. The remaining upper phase was washed with $3 \mathrm{~mL}$ of Sherlock Reagent 4 and mixed for $5 \mathrm{~min}$ to remove free fatty acids and residual reagents from the organic extract. The suspension was centrifuged at $2,000 \times \mathrm{g}$ for $5 \mathrm{~min}$ to separate to two phases completely. About $2 / 3$ of the upper phase extract solution was transferred to a clean GC sample vial using clean Pasteur pipette and analyzed by the 6890 Series GC system equipped with 7860 Series Injector (Agilent). Helium was used as the carrier gas. A $2 \mu \mathrm{L}$ injection volume of the samples was used. The injector temperature was $250^{\circ} \mathrm{C}$, the column temperature was increased from 120 to $240^{\circ} \mathrm{C}$ at a rate of $5^{\circ} \mathrm{C} \mathrm{min}{ }^{-1}$ and the gas chromatography-mass spectrometry transfer line temperature was $280^{\circ} \mathrm{C}$. Fatty acid methyl esters (FAMEs) were identified on the basis of their retention times and their mass spectra.

\section{G + C content of the genomic DNA}

The $\mathrm{G}+\mathrm{C}$ content of the genomic DNA was determined by HPLC according to the method described by Mesbah et al. (1989). Briefly, $25 \mu \mathrm{L}$ of DNA solution containing from 2 to $25 \mu \mathrm{g}$ of DNA in a 1.5 microtube was incubated at $60^{\circ} \mathrm{C}$ for $1 \mathrm{~h}$, then heated at $100^{\circ} \mathrm{C}$ for $2 \mathrm{~min}$, and rapidly cooled in an ice bath and flash centrifuged. An equimolar mixture of nucleotides for analysis of DNA base composition (Yamasa Shoyu, Choshi, Japan) was used as the quantitative standard. The standard solution, made up of $10 \mu \mathrm{L}$ of the above nucleotides and $15 \mu \mathrm{L}$ of sterile distilled water was prepared under the same condition. Then, $25 \mu \mathrm{L}$ acetate buffer $(40 \mathrm{mM}, \mathrm{pH} 5.3)$ containing $2 \mathrm{mM} \mathrm{ZnSO}_{4}, 20 \mu \mathrm{L}$ sterile distilled water, and $5 \mu \mathrm{L} \mathrm{P1}$ nuclease solution $\left(20 \mathrm{U} \mathrm{mL}^{-1}\right)$ were added to the DNA solution and incubated at $37^{\circ} \mathrm{C}$ for $2 \mathrm{~h}$. Then $2.5 \mu \mathrm{L}$ of glycine buffer $(0.1 \mathrm{M}, \mathrm{pH}$ 10.4) and $2 \mu \mathrm{L}$ of $1 / 10$ alkaline phosphate were added to the DNA solution and incubated overnight at $37^{\circ} \mathrm{C}$. After the incubation period, $10 \mu \mathrm{L}$ of the sample solution was injected into the HPLC equipped with a 5C18R Cosmosil column (Nacalai Tesc), and 0.2M ammonium phosphateacetonitrile (40:1) as solvent. The column temperature was maintained at $40^{\circ} \mathrm{C}$ with $1.0 \mathrm{~mL}$ per min speed and read at $270 \mathrm{~nm}$. The $\mathrm{G}+\mathrm{C}$ content was analyzed by Chromatopac using method 42 to obtain the factors C, G, T, and A.

\section{Results and Discussion}

\section{Identification of bacteria}

Strain C6d-NBRC $108627^{\mathrm{T}}$ was isolated from the non-axenic culture of Chlorella sp and formed colonies with a smooth surface, translucent white color, moist texture, raised elevation, and circular margin on tenfold Nutrient Broth agar. This strain was identified as a Variovorax bacterium based on the neighbourjoining tree (Figure 1). The nearly full length of the 16S rRNA gene sequence of strain C6d, positions 28 to 1491 (Escherichia coli 16S rRNA gene numbering) was compared with those of the type strains of Variovorax bacteria. Sequence similarities of the 16S rRNA gene between strain C6d and the type strains of $V$. bronicumulans, $V$. soli, $V$. paradoxus, $V$. ginsengisoli, and $V$. dokdonensis were 96.9\%, 96.7\%, 96.6\%, 96.6\%, and $88.9 \%$, respectively (Figure 1).

\section{Morphological and phenotypic characteristics}

The cell of the strain C6d was Gramnegative, motile using flagella and occurred as single cells, non-spore-forming, short and rodshaped (Figure 2). The cellular size was about 0.5-1.0 $\times 1.5-2.0 \mu \mathrm{m}$. According to Satola et al. (2013), cells of Variovorax are Gram-negative, motile, and oval or rod-shaped, motile with flagella and live in pairs or single cells, straight to slightly curved rods and the size are amounts to $0.3-0.6 \times 0.7-3.0 \mu \mathrm{m}$, yellow colonies, slimy, and shiny. The morphological characteristics of strain C6d were nearly the same of other members of the genus Variovorax.

\section{Chemotaxonomic analysis}

The dominant isoprenoid quinone of strain C6d was ubiquinone $8(\mathrm{Q} 8)$ as the same as the other type strains of the genus. The major fatty acid composition of this strain was summed feature 3, 16:0, and 18:1:w7, comprising more than $80 \%$ in total (Table 1). Summed feature 7 and summed feature 4 were detected in all members of this genus but not detected in strain C6d. These two fatty acids were probably 
Table 1. Cellular fatty acid profiles of strain C6d

\begin{tabular}{ccc}
\hline Fatty acid & C6d \\
\hline $\mathrm{C} 10: 03 \mathrm{OH}$ & - \\
$\mathrm{C} 12: 0$ & 1.1 \\
$\mathrm{C} 14: 0$ & 1.4 \\
$\mathrm{C} 14: 02-\mathrm{OH}$ & - \\
$\mathrm{C} 15: 0$ & 1.5 \\
$\mathrm{C} 16: 0$ & 25.8 \\
$\mathrm{C} 17: 0$ & 0.94 \\
$\mathrm{C} 17: 0$ cyclo & 5.0 \\
$18: 1$ w7c & 17.4 \\
Summed feature $3^{\mathrm{a}}$ & 37.9 \\
\hline
\end{tabular}

Note: ${ }^{a}$ Summed features are groups of two or three fatty acids which cannot be separated by GLC with the MIDI system. Summed feature 3 consisted of the following fatty acid: $16: 1 \mathrm{w} 7 \mathrm{c} / 15$ iso $2 \mathrm{OH}$.

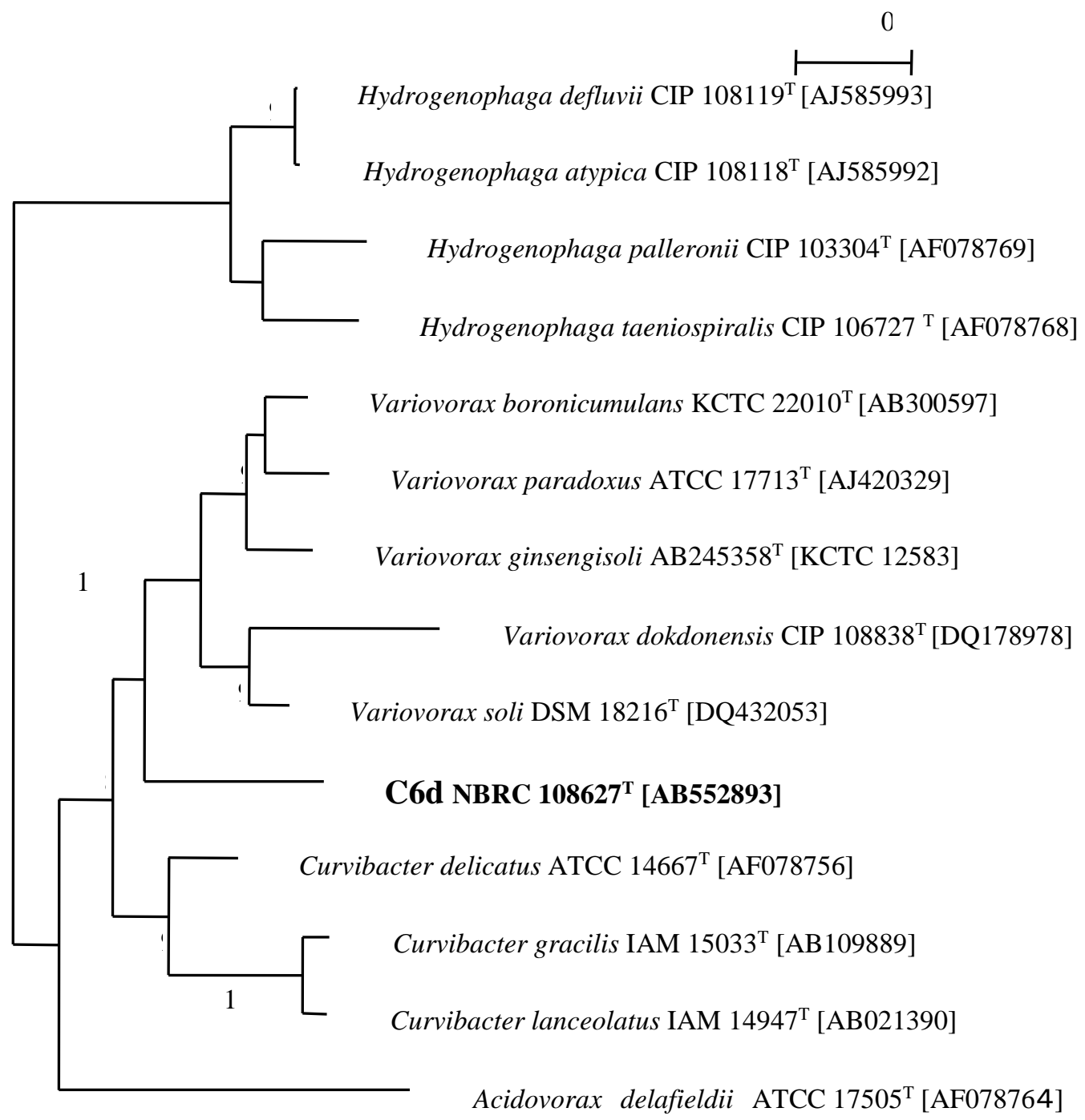

Figure 1. Neighbour-joining tree constructed based on the nearly full length of the 16S rRNA gene sequences of the bacterial strain $\mathrm{C} 6 \mathrm{~d}$ and their phylogenetically close species. The number of nodes indicate the bootstrap value of occurrence in 1000 trials (only values greater than $700(70 \%)$ are shown). 


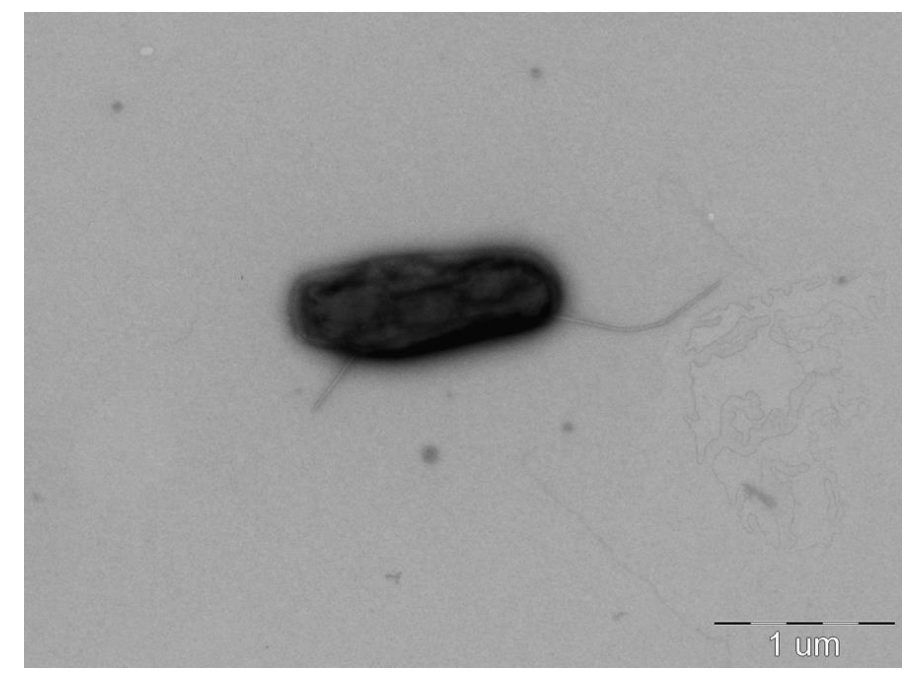

Figure 2. Transmission electron microscopy picture of Variovorax sp. C6d

identified as $18: 1 \mathrm{w} 7 \mathrm{c}$ and summed feature 3 in the present study. The differences in minor fatty acid composition between strain C6d and the type strains of Variovorax can also be attributed to the differences in culture conditions such as media used for cultivating the strain for fatty acid analysis. In this study, 1/10 NB was used but in the other studies, R2A was used as the medium to grow the strains. The DNA G+C content of strain C6d was $70.4 \mathrm{~mol} \%$, which was within the range of 66.0 to $71.2 \mathrm{~mol} \%$ of the genus Variovorax (Im et al. 2010; Tuan et al., 2018).

\section{Characterization and description of Variovorax C6d}

The cell was Gram-negative, motile, nonspore-forming, short and rod-shaped (0.5-1.0x 1.5-2 $\mu \mathrm{m})$ (Figure 2). Colonies were white in colour after 7 days on 10-fold diluted Nutrient Broth. The strain was able to tolerate $\mathrm{NaCl}$ to $1.0 \%$ but not to $4.0 \%$, and grew well at 10 to $30^{\circ} \mathrm{C}$ but did not grow at 4 and $37^{\circ} \mathrm{C}$. Strain C6d was positive for nitrate reduction and also for oxidation of D-trehalose, D-cellobiose, gentiobiose, sucrose, D-turanose, stachyose, Dgalactose, 3-methyl glucose, L-lactate, Lhistidine, malate, D-fucose, L-fucose, Lrhamnose, inosine, myo-Inositol, glycerol, Dglucose-6- $\mathrm{PO}_{4}, \mathrm{D}$-fructose-6- $\mathrm{PO}_{4}, \beta$-methyl-Dglucoside, $\mathrm{N}$-acetyl-D-glucosamine, $\mathrm{N}$-acetyl-Dgalactosamine, N-acetyl-neuraminic acid, Nacetyl-D-galactosamin, D-aspartic acid, L- arginine, L-glutamic acid, L-serine, L-histidine, Lpyroglutamic acid, D-gluconic acid, Dglucoronic acid, glucuronamide, mucic acid, quinic acid, D-saccharic acid, D-malic acid, Lmalic acid, L-lactic acid, and $\alpha$-keto-glutaric acid, as sole carbon sources, but negative for dextrin, D-maltose, D-raffinose, $\alpha$-D-lactose, Dmelibiose, $\alpha$-D-glucose, D-manose, D-fructose, D-sorbitol, D-manitol, D-arabitol, gelatin, glycyl-L-proline, L-alanine, D-serine, Dgalacturonic acid, L-galatonic acid lactone, propionic acid, acetic acid, citric acid, acetoacetic acid, methyl pyruvate, tween 40 , Dlactic acid methyl ester, bromo-succinic acid, gamma aminobutyric acid, p-hydroxylPhenylacetic acid, $\alpha$-hydroxyl-butyric acid, and $\beta$ - hydroxyl-D,L-butyric acid (Table 2). The major cellular fatty acids are C16: 0 , summed feature 3, and C18:1w7c. Q-8 was the predominant isoprenoid quinone. The $\mathrm{G}+\mathrm{C}$ content of the genomic DNA was $70.4 \mathrm{~mol} \%$. The strain was C6d ${ }^{\mathrm{T}}\left(=\mathrm{NBRC} 108627^{\mathrm{T}}\right)$.

\section{Conclusion}

The results of this study showed that Variovorax not only occurs in contaminated soils and groundwater, but also associates with algae. The strain C6d -NBRC $108627^{\mathbf{T}}$ isolated from the nonaxenic algal culture had all of the characteristics of the members of Variovorax. These results provide to a chance for continued research on the potential of using C6d in the field 
Table 2. Physiological characteristics of strain C6d

\begin{tabular}{llc}
\hline Characteristics & C6d \\
\hline Cell shape & Rods \\
Cell width $(\mu \mathrm{m})$ & $0.5-1.0$ \\
Cell length $(\mu \mathrm{m})$ & $1.5-2.0$ \\
Nitrate reduction & + \\
Urease & - \\
a-Glucosidase & - \\
D-Glucose & - \\
L-Arabinose & - \\
D-Mannose & - \\
D-Mannitol & - \\
Gluconate & + \\
Adipate & - \\
Citrate & w \\
Phenylacetate & - \\
D-Sorbitol & - \\
DNA G+C content $(\mathrm{mol} \%)$ & 70.4 \\
\hline Weakreactions & & - \\
\hline
\end{tabular}

Note: +, positive; -, negative; $w$, weak reactions.

of reclamation of polluted soil and the environment.

\section{Acknowledgements}

We are grateful to Prof. Keishi Senoo and Assoc. Prof. Shigeto Otsuka, the University of Tokyo, Japan, for their valuable advice on many of the stages of completing this study.

\section{References}

Ashida N., Ishii S., Hayano S., Tago K., Tsuji T., Yoshimura Y., Otsuka S. \& Senoo K. (2010). Isolation of functional single cells from environments using a micromanipulator: application to study denitrifying bacteria. Applied Microbiology and Biotechnology. 85: 1211-1217.

Ausubel F. M., Brent R., Kingston R. E., Moore D. D., Seid-man J. G., Smith J. A. \& Struhl K. (1995). Preparation and analysis of DNA. In: Ausubel F.M., Brent R., Kingston R. E., Moore D. D., Seidman J. G., Smith J. A. \& Struhl K. (Eds.) Current Protocols in Molecular Biology. Wiley, New York: 2-11; 109-111.

Cole J. R., Chai B., Farris R. J., Wang Q., Kulam-SyedMohideen A. S., McGarrell D. M., Bandela A. M., Cardenas E., Garrity G. M. \& Tiedje J. M. (2007). The ribosomal database project (RDP-II): introducing my
RDP space and quality controlled public data. Nucleic Acids. 35: 169-172.

Collins M. D. \& Jones D. (1981). Distribution of isoprenoid quinone structural types in bacteria and their taxonomic implication. American Society for Microbiology. 45(2): 316-354.

Futamata H., Nagano Y., Watanabe K. \& Hiraishi A. (2005). Unique kinetic properties of phenol-degrading Variovorax strains responsible for efficient trichloroethylene degradation in a chemostat enrichment culture. Applied Environmental Microbiology. 71: 904-911.

Gerhardt P., Murray R. G. E., Wood W. A. \& Krieg N. R. (1994). Methods for General and Molecular Bacteriology. Washington, DC: American Society for Microbiology.

Han J. I., Choi H. K., Lee S. W., Paul M. O., Kim J., Sarah L. R., Kim T. G., Jennifer O. N., Jared R. L., Sang Y. L., Hur C. G., Jim C. S., Galina O., Goodwin L. \& Han C. (2011). Complete genome sequence of the metabolically versatile plant growth-promoting endophyte Variovorax paradoxus S110. Journal of Bacteriology. 193: 1183-1190.

Ichimura T. (1971). Sexual cell division and conjugationpapilla formation in sexual reproduction of Closterium strigosum. In: Nishizawa K. (Ed.). Proceedings of the $7^{\text {th }}$ International Seaweed Symposium, University of Tokyo Press, Tokyo: 208-214.

Im W. T., Liu O. M., Lee K. J., Kim S. Y., Lee S. T. \& Yi T. H. (2010). Variovorax ginsengisoli sp. nov., a denitrifying bacterium isolated from soil of a ginseng 
field. International Journal of Systematic and Evolutionary Microbiology. 60: 1565-1569.

Jennifer A. C. (2019). Investigating the Functions of the Plant-associated Genus Variovorax in the Populus Rhizosphere. Masters Theses. University of Tennessee, Knoxville.

Kim B. Y., Weon H. Y., Yoo S. H., Lee S. Y., Kwon S. W., Go S. J. \& Stackebrandt E. (2006). Variovorax soli sp. nov., isolated from greenhouse soil. International Journal of Systematic and Evolutionary Microbiology. 56: 2899-2901.

Kristina M. M., Zheng H., Tekle T. F., Ronald J. P., David E. G. \& Jim C. S. (2017). Iron-Dependent Enzyme Catalyzes the Initial Step in Biodegradation of NNitroglycine by Variovorax sp. Strain JS1663. Applied Environmental Microbiology. 83(17). DOI: 10.1128/AEM.00457-17.

Larkin M. A., Blackshields G., Brown N. P., Chenna R., Mcgettigan P. A., Mcwilliam H., Valentin F., Wallace I. M., Wilm A., Lopez R., Thompson J. D., Gibson T. J. \& Higgins D. G. (2007). Clustal W. and Clustal X. version 2.0. Bioinformatics. 23: 2947-2948.

Mesbah M., Premachandran U. \& Whitman W. B. (1989). Precise measurement of the $\mathrm{G}+\mathrm{C}$ content of deoxyribonucleic acid by high performance liquid chromatography. International Journal of Systematic Bacteriology. 39: 159-167.

Miwa H., Ahmed I., Yoon J., Yokota A. \& Fujiwara T. (2008). Variovorax boronicumulans sp. nov., a boronaccumulating bacterium isolated from soil. International Journal of Systematic and Evolutionary Microbiology. 58: 286-289.
Otsuka S., Abe Y., Fukui R., Nishiyama M. \& Senoo K. (2008a). Presence of previously undescribed bacterial taxa in non-axenic Chlorella cultures. The Journal of General and Applied Microbiology. 54: 187-193.

Saito T., Ishii S., Otsuka S., Nishiyama M. \& Senoo K. (2008). Identification of novel Betaproteobacteria in succinate-assimilating population in denitrifying rice paddy soil by using stable isotope probing. Microbes and Environments. 23: 192-200.

Satola B., Wubbeler J. H. \& Steinbuchel A. (2013). Metabolic characteristics of the species Variovorax paradoxus. Applied Microbiology and Biotechnology. 97: 541-560

Tuan N. M., Ngoc T. H. \& Kim J. (2018). Proposal of three novel species of soil bacteria, Variovorax ureilyticus, Variovorax rhizosphaerae, and Variovorax robiniae, in the family Comamonadaceae. Journal of Microbiology. 56: 485-492.

Yoon J. H., Kang S. J. \& Oh T. K. (2006). Variovorax dokdonensis sp. nov., isolated from soil. International Journal of Systematic and Evolutionary Microbiology. 56: 811-814.

Vu H. T., Otsuka S., Ueda H. \& Senoo K. (2010). Cocultivated bacteria can increased or decreased the culture lifetime of Chlorella vulgaris. The Journal of General and Applied Microbiology. 56(5): 413-418.

Willems A., De Ley J., Gillis M. \& Kersters K. (1991). Comamonadaceae, a new family encompassing the Acidovorans rRNA complex, including Variovorax paradoxus gen. nov., comb. nov., for Alcaligenes paradoxus (Davis 1969). International Journal of Systematic Bacteriology. 41: 445-450. 